\title{
A Brief Discussion on the News Media of Modern Korea
}

\author{
Kim Yongkyoung ${ }^{1}$ \\ ${ }^{1}$ School of Journalism and Communication, Tsinghua University, Beijing, China \\ Correspondence: Kim Yongkyoung. E-mail: winker21@hotmail.com
}

Received: March 29, 2018

Accepted: May 3, $2018 \quad$ Online Published: June 22, 2018

doi:10.5539/ass.v14n7p53

URL: https://doi.org/10.5539/ass.v14n7p53

\begin{abstract}
The relationship between the ancient and modern China with the Korean Peninsula can be summed up using the term "fed by the same river", meaning neighbours separated by only a strip of water. Especially with the efforts of both China and Korea, the ancient East Asia region has created a splendid culture and has been the leaders in the world for a long period of time. However, by the end of the 19th century, the Japanese imperialist forces had always tried to 'Conquer the Korean Peninsula,' and, in 1910, the Korean Peninsula finally became a Japanese colony. After entering the modern era, one of the phenomenas manifested in the information flow in East Asia is the rapid development of media in China and Japan due to the increase in newspapers and magazines issued by the West.

190 years ago, Chosun Dynasty under the Lee Family had continuously initiated the modernization movement in the Korean Peninsula, through introducing modernization productions from the West, the Qing Dynasty and Japan. In the modernization process, the opposition between "ethnography" and "pro- Japanese Korean" have resulted social conflicts.
\end{abstract}

Keywords: Korean Peninsula, modernization, news media

\section{The Birth of Modern News Media}

\subsection{The History of the Newspapers in the Korean Peninsula}

The newspaper ${ }^{1}$ was the most concrete symbolic achievement in the modernization period of the late 19th century. When the Chosun Dynasty ${ }^{21}$ and the Western powers signed a treaty, the newspaper, a foreign cultural relic, was introduced in the Korean Peninsula, and also it passed on to the outside world about Chosun's various kinds of information.

China's ancient newspapers had reached the peak in the mid-Qing Dynasty period. However, they did not evolve directly into modern newspapers as of the Western's. In China, the upsurge of colonial expansion set off. Immediately, Foreigners reporting in China began to appear and it continued.

After the Japanese imperialists used force to open the gate of the Lee Family's Chosun Dynasty in 1876, the "Gwanghwa Island Treaty" was signed. Afterwards, relations between the Chosun Dynasty and Qing Dynasty experienced dramatic changes when the "Imo Military Incident" in 1882, and in1884 "the Gapsin Coup", and Sino-Japanese War break out in 1894. The involvement of the Japanese imperialist forces in the Korean Peninsula caused the Qing Dynasty's attention. The involvement of the Japanese imperialist forces in the Korean Peninsula attracted the attention of the Qing dynasty. This led to a series of diplomatic struggles between the Qing Dynasty and Japanese imperialists to compete for the power of the Korean peninsula. Until 1894, as the Sino-Japanese War broke out and the forces of the Qing Dynasty gradually withdrew from the Korean peninsula. Japan seized the Korean Peninsula's dominant power.

After the Sino-Japanese war and the war against Tsarist Russia, finally on August 22, 1910, Japanese imperialists surrounded the Imperial Palace of the Korean Empire ${ }^{3}$ to compel the emperor ${ }^{4}$ of the Chosun Dynasty to ratify

\footnotetext{
1 To prevent confusion, this paper translated “新闻报纸” as “Newspaper”.

21392 to 1910. However, in 1897, the Emperor Gojong changed the "Korea Empire."

3 The Korean Empire (1897 1910)

4 1874 1926. During the emperor's reign 1907 1910.
} 
the "Korea-Japan Merger Treaty ${ }^{5}$." After the signing of this treaty, the Korean peninsula was deposed as a colony of Japanese imperialism.

In the Lee's Chosun Dynasty, the "Morning Newspaper" played the role of a modern newspaper. According to the Professor Kim Yeung-soo of Kyungnam University in South Korea, the profit-making printed version of "Morning Newspaper" in 1577 was 70 years earlier than the world's earliest published German newspaper. During this period, the "Morning Newspaper" was an official communique that was used to introduce administrative services. It was confined to read by central and local authorities, and the content was also partially public.

In April 2017, Master of Longhua Temple in South Gyeongsang Province in South Korea owns a printed "Morning Newspaper" issued in mid-November 1577. On the fifth page of the newspaper, there are many interesting news stories, one of which is reported as following: "A bovine plague occurred in Hanyang. More than 600 cattle died on the roadside. The people were crying out and the scene was unbearable. (November 15th, 1577) The plague came from the process of transporting ice cubes, an infectious disease similar to foot-and-mouth disease occurred, and a large number of cattle got a plague (November, "Morning Newspaper", date not clear).

The "Morning Newspaper" also reported in the report: "If you continue to be forced in imprisonment, you will only make the grievances of the people getting louder and harder, and eventually impossible to calm down." In addition, for this unusual climate, the court ministers have turned in their resignations in order to get forgiveness and have been rejected by the King. At the same time, the monarch blamed the disaster for their own misfortune.

In addition, in the report, criticized the soldiers for riding a luxury sedan chair. "As a general of a country, it was supposed to lead troops to fight on horseback, but they would sit in a comfortable sedan chair, and if there was a war doubt they could protect the country." The "Morning Newspaper" not only publishes various regions and officials' reports, but also a monarch's sin. According to a professor Kim Youngjoo from Gyeongnam University, the "Morning Newspaper" nakedly exposed social politics and folk remnants. Nothing was inferior to today's public opinion.

However, 100 days earlier, starting in August, the unemployed intellectuals in Seoul (used to be "Hanyang") received permission from the government ${ }^{6}$ and began to subscribe for printing and distribution. According to the record of $\mathrm{Li} \mathrm{Yee}^{7}$ (1536 1584) "Suk Dam Diary "': "Most of the readers of the newspaper are very satisfied."

On November 28th, 1577, King Seonjo of the 14th King of the Chosun Dynasty was infuriated about this incident. After hearing the news, the King Seonjo was furious and immediately commanded "arrestment," that is, arrest all the people involved in privately printed and sold "Morning Newspaper". The 30 individuals involved in the issuance of the "Morning Newspaper" have suffered severe tortures. The secretary of the Constitutional Act ${ }^{9}$ cannot wait to beg the King Seonjo: "They did not commit crimes on purpose. They just wanted to earn a subscription fee. "However, Seonjo's anger has not disappeared and he had eventually ordered to expel them to exile. Then the "Morning Newspaper" continued for only more than 100 days. Under the crackdown of public opinion, it was forced to suspend publication. ${ }^{10}$

\subsection{The Birth of Modern Newspapers}

After the 19th century, one of the phenomena manifested in East Asian information circulation is the increase of newspapers and magazines issued by westerners and the emerge of modern media influenced by the China and Japan.

During the Chosun Dynasty, Chosun sent the envoys to Qing and Japanese Island to adopt the issuance of newspapers. After the signing of the Ganghwa Island Treaty (1876), it was the Japanese who opened the port first. The Japanese people living in Busan issued the Japanese version of the "Korean News Daily" in 1881. With

\footnotetext{
5 Korean people said the "Korea-Japan Merger" in 1910 as "Geungsul Guk Qi" which means a national shame.

6 The highest administrative institution of the Chosun era.

7 16th century famous Confucian scholar and politician in the Chosun Dynasty

${ }^{8}$ Dialogue between ministers and monarchs. In the period from 1565 to 1581 , Lee Yi recorded in detail the main events and people of the time.

${ }^{9}$ One of the government agencies of the Chosun Dynasty. Speech activities, customs corrections, bureaucratic impeachment, etc.

10 "Discovery of the earliest newspaper in the world the "Morning Newspaper" in Chosun Dynasty" Kyunghyang Newspaper 2017.04.18
} 
the introduction of these new information in the Korean society, the understanding and concern of the intellectuals in modern Korea for modern newspapers has been further deepened. ${ }^{11}$

The world press begins to move toward the commercial newspaper stage. Western capitalist countries developed by leaps and bounds. With the expansion of the world, Western colonists not only carried their national newspapers into the colonial countries, but also established newspapers with the sovereign power within the colonies.

The "Hangsung Report" is the earliest modern newspaper in the history of the Korean Peninsula. Founded on October 31,1883, it is under the charge of the Bowen Bureau, which belongs to the Chosun dynasty. The paper was actually initiated by the Korean government after accepting the suggestion of the Kailash Party ${ }^{12}$ person Park Yong-hyo (1861-1939) that it actually took over the paper but it was a moderately liberalized school. (Kim min su, 1978)

Park Yong-hyo is the first person in the modern history of Korea to advance the press. In 1882, in order to calm down the chaos, he traveled to Japan as a "Plenipotentiary Minister and a messenger". ${ }^{13}$ There are a total of 14 people in this group including Park Yong-hyo, Deputy Governor Kim Sang-sik (1834-1900), Officer Soo GuangHuan (1859-97) and Jin Yujun (1854-1894)

At the time, after the Meiji Restoration in Japan, he witnessed a great change. Among them, the vigorous development of the Japanese newspaper industry has been deeply inspired. On January 6, 1883, he resigned and returned to the Korean peninsula. Subsequently, on the following February 6th, he was appointed as "Hangsung Officer ${ }^{14,}$ (equivalent to the current Seoul Mayor)." From February 28th, he was responsible for the newspaper publishing business ${ }^{15}$. After Hangsung government took over the newspaper publishing business, Park Young-hyo appointed Yu Giljun (1856 1914) to manage other things ${ }^{16}$.

When Yu Giljun (1856-1914) was studying in Japan, he was deeply influenced by modern knowledge and was an intellectual of Kaifa Party. In 1881, he took part in the "Academic Visit" for the entourage of Eu Yoonjeng (1848 1896), and Yoon Qiho (1865 1945) studied at Keio University, founded by Fukuzawa Yuki, Japan ${ }^{17}$. (Zheng Jinxi, 2013)

After the military outbreak in 1882, Yu Giljun received an invitation from the Korean Peninsula (1860-1914) to go back to the Korean Peninsula and devote himself to the Korean civilization movement. He worked with "Niu Chang Zhuo Zao", "Takahashi Masaru", and "Inoue Kazuo", etc. to prepare for newspaper publication. The three editors were recommended by Fukuzawa Yuki and personally recruited from Japan by Park Yong-hyo ${ }^{18}$.

Lee's Chosun Dynasty established the agency that took charge of compiling and printing newspapers and magazines in Seoul in 1883, and published the first modern newspaper "Hansung Report" in October 30th the same year. The "Hansung Report" was issued three times a month using movable printing machines imported from Japan. It was the official newspaper written in soft Chinese.

Its nature is similar to that of China's Qing Dynasty official newspaper. There are five editors of modern news newspapers published by the government, including a Japanese man, Inoue Kokuro, who translate news from foreign newspapers into Chinese. Editors' reticence and reconciliation is a newspaper that must be read by intellectuals.

The content is about domestic situation in Korean peninsula such as price trends, social news, foreign news, comments, etc., especially the geography, science, politics, and culture of Western countries were involved. However, on December 6, 1884, the "Hangsung Report" facilities were destroyed by mobs because of its involvement in the Openness Party, after being told that it had involved in the "Gapsin Coup." The Publication Bureau ("PakMun Gook") was destroyed and the "Hansung Report" had to be suspended. Although the issuance period is short, and the official leads the use of Chinese boundaries, the "Hansung Report" is basically a condition for modern newspapers and was recognized as the earliest modern news newspaper on the Korean

\footnotetext{
11 "School of Sengjung" Gojong 19 years (1882) November 18th.

12 Kim min su, History of the Nationalist Theory of the Japanese Empire, ilwolbooks, May 1978, p. 9

13 "Gojong Shillok" Volume 19, Gojong 19 years (1882) August 8 (Shillok); Park Yong Hyo, "Impression" and August 1).

14 "School of Sengjung Journal" Gojung 19 years (1882) November $28^{\text {th }}$; December 29th

15 "School of Sengjung Journal" Gojung 20 years (1883) January 21st

16 Zheng Jinxi, "Study on the "Hangsung Newspaper"”, Official Journal (1983), p. 36

17 Zheng Jinxi, "Korean News History”, Communication Books, February 2013, p. 18

18 Lee Kwang rin, "A Survey of the "Hangsung Newspaper", Journal of History 38 (1968), p. 3
} 
peninsula ${ }^{19}$. (Kim min su, 1978)

A year later, on January 25, 1886, the publication was renewed in the name of "Seoul Weekly." Although Chinese characters were mainly used, Korean words were also used, and even pure Korean editions were issued. However, because of the loss, it was suspended when the Publication Bureau was abolished in 1888.

Later, Seo Jaepil (1864-1951), who was once involved in the Gapsin Coup from Openness Party, established the "Independent News" on April 7, 1896. This was the first private newspaper in the history of the Korean Peninsula. Not only that, the newspaper was written in pure Korean every other day, and the front page published doctrines and advertisements. The second edition and the third edition of the newspaper publish official newspapers, foreign newsletters, and social news. The fourth edition is edited in English. This newspaper is more focused on comments than news reports and has a unique enlightenment significance ${ }^{20}$.

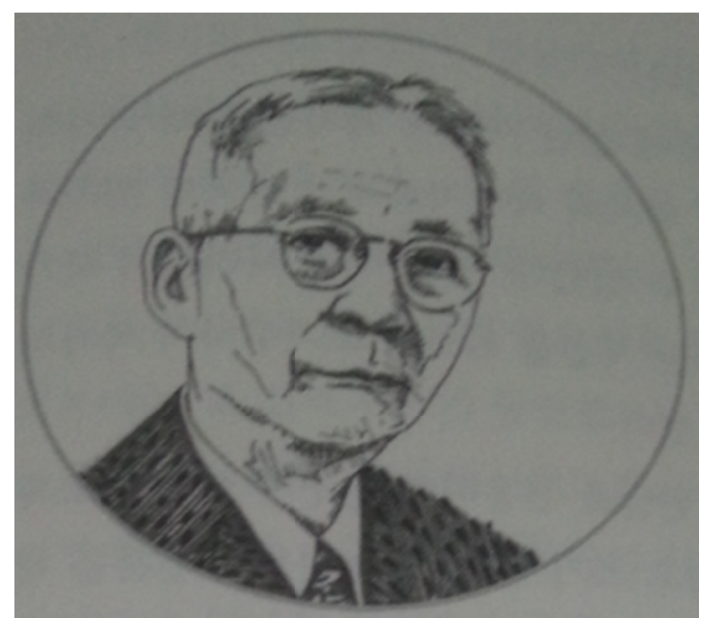

Figure 1. Seo Jaepil $\left(1864 \sim 1951^{21}\right)$

Regardless of character or content, "Independent News" has historical significance in the journalism in the Korean Peninsula. First of all, the paper used pure Korean for the first time instead of Chinese characters, which not only facilitates popularization but also contributes to the consistency of Hangul. This is about 20 years earlier than the Chinese vernacular movement in the early 20th century. In addition, the English version of "Independent News" was also published, and it disseminated abroad the summary of current affairs and public opinions in the country. "Independent News" vigorously promoted independent thinking and strongly opposed foreign forces, called for the Korea's independence, also made great contributions to the Korean people's enlightenment. Since 1898, "Independent News" has been changed to a daily publication until December 4, 1899, then the newspaper was suspended after it was acquired by the government.

Since the publication of "Independent News", there have been the emergence of newspapers among local Koreans. After the first daily newspaper of the Korean Peninsula, "Daily News", was launched in 1898, there had been other daily newspapers such as "Hwang Sung News" and "Royal News".

Chang Ji Yeon $(1864 \sim 1921)$ and others bought the "Korea Royal News" and changed its name to "Royal News." The newspaper adopted both of Korean and Chinese characters, and it is mainly for readers of medium and high knowledge level people. "Imperial News" was written in a purely Korean character for general public and women, which has carried out a revolutionary argument. It is suspended when the "Korea-Japan merger" occurred in $1910^{22}$.

\section{The Role of Modern News Media}

\subsection{Civil Rights Awareness and National Unity}

The source of how to grasp the interrelationship of the rights of the people and authoritarian monarchs is the evidence of the Civilization Party's thought. The Civilization Party provided the people with the conditions for

\footnotetext{
${ }^{19}$ Kim min su, The History of the Japanese Nationalists' Remarks on Forced Occupation, ilwolbooks, May 1978, p. 10

${ }^{20}$ Kim min su, The History of the Japanese Nationalists' Remarks on Forced Occupation, ilwolbooks, May 1978, p. 11

${ }^{21}$ Zheng Jinxi, "Korean News History”, Communication Books, February 2013, Page 25

22 Zheng Jinxi, "Korean News History”, Communication Books, February 2013, Page 8
} 
the establishment of a modern nation. The Civilization Party's concern for civil rights was more limited than at the time. Therefore, Civilization Party put principle of the education on the people's equality, they emphasized enlightenment of the people through education ${ }^{23}$. (Jo min, 1988) This is the basis for the modern national awareness, or the basis of national identity.

This kind of concern for education is different from that of "Dongdao Xiqi Party" that only cares about the physical advancement. The Civilization Party also admitted that people's nation cannot be achieved without wealth and strong army. However, their point is that if country has no rise of modern people's nation, it should be the education system for people that should be practiced to achieve modernization.

When the great powers invaded Asia reached its climax, people did not surrender but instead held the banner of independence up high. The "Royal News" is a kind of folk newspaper issued during the Chosun Dynasty period. It uses Chinese as a main language, but still mixed Korean and Chinese characters. The newspaper was founded on September 5, 1898, and was suspended for publication on September 15, 1910. Famous members include Ji Yeon Chang, Eun Sik Park, and Uk Nangong. The reader of the "Royal News" is mainly composed of two groups, one is targeting Confucianism, etc., and the other for the general public, which in contrast is written pure Korean "Independent News" and "Imperial News".

The "Royal News" and the "Korea Daily News" can be regarded as the duo media of Korean public opinion during the period of the patriotic Enlightenment. These newspapers have actively promoted modern civilization to promote nationalism. However, at the same time, it also retains traditional values, especially the enthusiasm for the inheritance of practical learning, and it is somewhat conservative as a position of enlightenment.

At the same time, "Royal News", another famous patriotic newspaper, after the signing of the 1905 "Eulsa Treaty." Ji Yeon Chang published in the paper titled "Crying out loudly in the morning" and thus cease publication for more than 80 days.

However, the newspaper is generally relatively gentle and opposed the Japanese movement. After the Korean Empire has fallen in 1910, it was renamed "Hansung News" and no longer ceased publication due to financial difficulties.

\subsection{World Recognition and National Subjectivity}

Before the mid-nineteenth century, the Qing-Chosun tributary relationship to a large extent took the form of rituals such as "tribute" and "proclaiming the Heir" and thus appeared loose. The tributary system is a political system characterized by tribute which exists between Qing dynasty and most of its neighboring dynasties. This system will inevitably move to disintegration as Western countries expand their influences into Asia.

In the 19th century, the international order in Asia was divided into two types: one was the tributary system and the other was the feudal state relations. After the founding of the Qing dynasty, through the use of force to conquer and inherit the relationship of the Ming dynasty, the Qing had become the suzerain state and established seven vassal states and formed the East Asia "HuaYi" Order." The other is the colonial system, which was due to the mad expansion of the great powers in the mid-19th century. With their expansion, most Asian countries have become colonies and semi-colonies. The capitalist powers established a colonial relationship in Asia. There is a fundamental difference between the tributary system and the colonial system. The former is the feudal attachment of monarchs and the latter is the relationship between occupation and being occupied, enslavement and being enslaved, exploitation and being exploited.

Daeyong Hong (1731-1783), Jega Park (1750-1805), and Yakyong Jeong (1762-1836) criticized the scholars of the Chosun Dynasty for the Chinese world order and the perspective of world. Daeyong Hong proposed a new perspective that oppose to the Chinese view of the world. Chinese view was that all parts of the world may become the center of the world. In particular, Jiwon Park (1737-1805) criticized that "If it is in the interests of the common people, it is in the interest of the country," and criticized that the "Chinese" would fall, and also criticizing as "Little China" and "Little Chinaism".

The scholars mentioned above are overwhelming the world view of science over the traditional world view, and it has a broad meaning that it is the challenge to the view of "Huayi." This phenomenon of China is a reality for China's neighboring nations. By breaking this view of the world to achieve national self-esteem, in order to explore the way of national self-survival.

Therefore, the "Hangsung Report" started to publish the "Huayi" world view with the content of "Theory of the

23 Jo min, "Korean Modernization and Evolutionary Movements," Korean Society of Modern and Contemporary History, sinseowon, 1988, p. 44 
Earth " from the first issue, which meant that it was separated from the view of "center of the world is China." In particular, through the contents of "World Geography" such as "Earth Graphic," "Continents and Oceans" and "Full Earth Map," it overcomes the difficulties of traditional world views at that time and Chosun's intellectuals in also strive to overcome the worldview of Orthodox Confucianism.

In addition, the "Hansung Report" ruled out the Qing dynasty, but it used Chosun's founding year and also revealed news reports of the Qing riots represented by Yuan Shikai. Such reports from "Hansung Report" will trigger the conservatives and diplomatic friction and pressure with the Qing Dynasty, and from the 4th edition implemented both the "Chosun Founding Year" and "Qing's Year". Especially reports from the Qing army will be triggered.

Western powers believe that in order to achieve their own business and regardless of their own interests, aggression and predation of all the public law. However, the "Seoul Weekly" warned that people in Africa, Asia, and the Americas were "invaded by the imperialist powers" and "warned Chosun to warn against imperialist aggression."

Therefore, it is also pointed out that the "extraterritorial jurisdiction" in the country, including unfair treaties such as Japan and other imperialist powers, will infringe autonomy.

Especially "Independent News." The paper clearly expressed the social responsibility of the media. Xu Zaiyu wrote in this autobiography: "I'm convinced that our country's independence lies in education, especially in inspiring the people. Therefore, we plan to publish newspapers first." The first issue of the newspaper was issued only 300 copies, but it was later increased to 3,000 copies per issue. Xu Zaiban used the experience learned from the United States to promote Western news values. In December 1899, Xu Zaiyu due to crowding out to United States newspaper ceased publication.

"Independent News" has become a torch in the history of the modern revolution. South Korea's public opinion inherited the spirit of "Independent News" and formed a tradition of anti-Japanese independence movement and resisting the tradition of dictatorship fighting for the defence of democracy.

The nineteenth-century Korean people gained new social consciousness through parallel newspapers during various incidents that occurred at the same period of time. This social consciousness forms the country, and its process is the responsibility that modern media needs to bear.

The symbolism of the modern media has become representative of the use of Korean. Although King Sejong, the fourth king of Chosun, created Hangul, Confucianists and Chineseism have discriminated against the Hangul. However, it is worth noting that the use of Korean in the modernization process means that it has the publicity. This is to get rid of the shackles of the "World of Chinese characters" and to pursue the modernization with Hangul. For example, in Western modernization, language is not neutral.

The development of national language in ancient Latin was the main reason for the collapse of the feudal society in Europe.

Therefore, the use of Korean has freed Korea from Chineseism, and the language made people to think about the world. The Hangul is the start to modernization and discover the formality of the nation. That is to say, it is the basis of the independent newspaper in pure Korean version will be set by the "Seoul Weekly."

Therefore, the symbolic function of modern Chosun media derives from "Hangul." The Hangul rejects the Chinese order based on "Huayi" concept and establishes a "world knowledge" based on the theory of social evolution, thus becoming the medium of education.

When Park Yong-hyo, who first came up with the Chosnn flag, promoted the issuance of modern newspapers, and Kil-chun $\mathrm{Yu}^{24}$, who was responsible for practical matters, left behind list of the mixed use of Korean and Chinese vocabulary to publish and the description. He also showed the possibility of using Korean as the main language in newspaper. However, as Park Soong-hyo was demoted to Seoul and became the mayor the plan of Kil-chun Yu was frustrated, and the opposing opinion of "Seoul Weekly" has changed. The language of the newspaper has again changed back to pure Chinese.

However, after the publication of the "Hangsung Report" suspended, the name of the "Hangsung Report" was renamed in "Seoul Weekly" in 1886. The newspaper was then written in pure Chinese, Mixture of Chinese and Korean, and pure Korea. This means that since the "Seoul Weekly" is a government agency report issued by the

${ }^{24} \mathrm{Yu}$ Kil-chun (1856 1914). The late modern revolutionary in Japan. 
state agency "Publication Bureau", it can be said that it has a great historical significance. ${ }^{25}$ It is said that the "Seoul Weekly" using the Hangul not only praises ordinary readers, but even raises support for the Emperor Gojong. 26

In particular, "Independent News" is a purely Korean newspaper. For the Wednesday issue, four editions were written in pure Korean and English texts, three in Korean and one in English. The purpose of using the Hangul instead of the Chinese characters is mainly to arouse ordinary people. Readers include citizens, intellectuals, and foreigners. "Independent News" issued a total of 776 issues in Hangul and 442 issues in English. In commemoration of the newspaper, Korean press set April $7^{\text {th }}, 1957$ as the "Newspaper Publication Day."

\section{Korea-Japan Opposition "Ethnography" and "pro-Japan"}

\subsection{The Russo-Japanese War and News Media Policy}

In February 1904, following the start of the Russo-Japanese War, Japanese imperialist defeated Russia on the Korean peninsula in 1905, occupying a political monopoly.

The Korea-Japan agreement on February $23^{\text {rd }}$ allowed Japan to occupy the military areas in Korean peninsula, and another agreement in August $22^{\text {nd }}$ allowed Japan to interfere with the internal affairs of the Korean Empire.

Along with the road to subjugation, the Korean Empire split into a patriotic independence and pro-Japanese anti-nationalist camp on the Korean Peninsula in 1910. They maintain their own opinions and issue various newspapers. After the Russo-Japanese War, it exerted great pressure on the newspapers issued by the empire, which eventually led to the slackening of national public opinion. ${ }^{27}$ (Cha Baegen, 2001)

On the other hand, number of newspapers issued by Japanese in the Korean peninsula has increased sharply after the end of the Russo-Japanese War. Among them, the representative newspapers are distributed to Korean people in Korean, such as "Dae Han Daily" and "Daedong News." The publication of Japanese newspapers began to falsify. The "Seoul New Newspaper" ${ }^{28}$ originated in 1895. Japan's Ministry of Foreign Affairs was the financial backer of these newspapers, rationalizing the invasion of the Korean peninsula and defending the Japanese imperialist ambitions.

After the so-called "Eulsa Protection Treaty" in 1905, Japan also issued the "Kyungsung Daily" and the English newspaper "Seoul Press" to not only promote the political propaganda in the Korean peninsula but also to guide the Japanese imperialists' to international news on the Korean Peninsula.

Therefore, after the outbreak of the Russo-Japanese War in 1904, the media in the Korean peninsula was divided into two groups. Among the newspapers run by Koreans, except for the nationalists' newspaper, there were also pro-Japanese newspaper that is against the nationalism.

Therefore, it can be divided into "ethnography" and "pro-Japan". From the perspective of the supplier, it can be divided into Korean national business newspapers and foreigner newspapers.

After the outbreak of Russo-Japanese War, a variety of Korean newspapers and magazines were established on the Korean Peninsula. In addition to the "Royal News" and "Imperial News", Seoul and the other local areas also founded newspapers.

"Mansae Newspaper" (June 17th, 1906) is a newspaper approved by Lee Injik to be established as an organ of Heavenly agency. Two new technologies have been introduced in production. First, in Chosun, for the first time in Chinese, red Korean words are used to mark Korean pronouns so that even people who do not understand Chinese can read newspapers. Second, for the first time in the Korean Peninsula serialized novels were published in the newspaper.

The "Korean People's Daily" is a newspaper that was founded on June 2, 1909 by the "Korea Association". On August 29, 1910, after the "Korean-Japanese Merger," a total of 356 journals were published. "Kyunghyang News" was founded on October 19, 1909 by the French priest, An Shihua, and published by the Catholic Church. The "Gukmin Newsletter" was an organizing report of January 1, 1906, which was first published on January 6 , 1906.

${ }^{25}$ Cao Dongri, “General History of Korean Literature”, Knowledge Industry Society, 1986, pp. 223-224

${ }^{26}$ Choi Jun, "Korean News History”, Shichao Court, 1982.01.10, p. 28

${ }^{27}$ Cha Baegen, Wu Zhenhuan, Zheng Jinxi, Li Guangzai, “Our Newspaper for 100 Years”, Xuanyan Society, 2001, pp 58-59

${ }^{28}$ Zheng Jinxi, "100 Years of Korean Remarks from a Person's Perspective 11 Literati's Remarks - The End of Old Korean Emperor's Era", News and Communication, 1993, p. 39 
${ }^{29}$ In a situation where the fate of the country cannot be overlooked, National front to protect national sovereignty the pro-Japanese opposition to the Japanese aggression formed a confrontation. From the point of view of newspaper distribution sites, not only the territory of the Korean Peninsula, but also many newspapers issued in the United States and Russia, and there are also many Japanese-issued newspapers in the Korean Peninsula. Therefore, the situation in the press at that time was very diversified, and very complicated. The remarks in this period can be divided according to the issuing subject, issuing location, and language.

Table 1. News Media during early stage of Modernization in Korean peninsula

\begin{tabular}{|c|c|c|}
\hline & Contents & Name of the Media \\
\hline 1 & $\begin{array}{l}\text { Newspaper issued by Korean people in } \\
\text { Korean peninsula }\end{array}$ & $\begin{array}{l}\text { "Mansae Newspaper", "Korea people's Newspaper", } \\
\text { "Royal Newspaper" }\end{array}$ \\
\hline 2 & $\begin{array}{l}\text { Newspaper issued by foreigners in Korean } \\
\text { peninsula }\end{array}$ & $\begin{array}{l}\text { "Korea Daily News", "Korea Daily Newspaper", } \\
\text { "Daedong Newspaper" }\end{array}$ \\
\hline 3 & $\begin{array}{l}\text { Korean Newspaper issued by } \\
\text { Korean outside Korean peninsula }\end{array}$ & $\begin{array}{l}\text { "Gongli Newspaper"(United States), “New Korean } \\
\text { Newspaper"(United States), "Haecho Newspaper"(Russia) }\end{array}$ \\
\hline 4 & $\begin{array}{l}\text { Foreign Newspaper issued by foreigners in } \\
\text { Korean peninsula }\end{array}$ & $\begin{array}{l}\text { "Kyungsung Daily Newspaper", "Korea Daily(English), } \\
\text { "Seoul Press(English)"” }\end{array}$ \\
\hline
\end{tabular}

At the same time, Japanese imperialists made Japanese proficient in Korean directly issue newspapers or used faithful pro-Japanese Koreans to set up newspapers such as "Daehan Newspaper" and "Gukmin Newspaper" to cultivate pro-Japanese groups. After the Russo-Japanese War of 1905, Japan began to interrogate and suppress the Korean media directly, and for the first time established the "Newspaper Law" and the "Publishing Law," and the government of the Korean Empire will also regulate the media. Due to the prior review of the newspapers, measures such as seizure and sales by seizure measures frequently occurred.

The "Newspaper Printing Law ${ }^{30 "}$ promulgated by Lee Wanyong with the other officials in July 1907, it was criticized as law of the "Guangwu Newsprint Law. ${ }^{31}$ " Based on this, from the legal point of view, the press has been fundamentally controlled. The "Newspaper Law" was a tool to suppress public opinion during the Japanese imperialist domination, but it was not officially repealed until 1952 after the liberation in 1945.

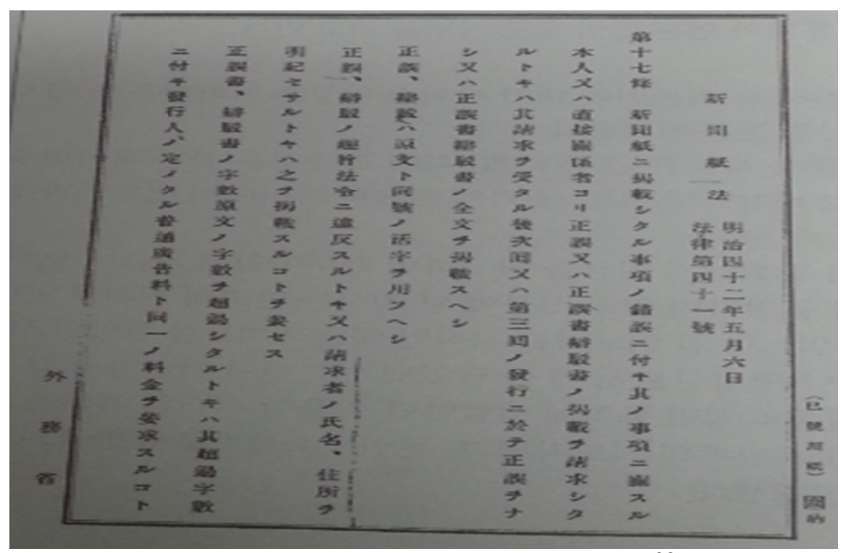

Figure 2. Newspaper Printing Law $^{32}$

\footnotetext{
29 Zheng Jinxi, “100 Years of Korean Remarks from a Person's Perspective 11 Literati's Remarks - The End of Old Korean Emperor's Era", News and Communication, 1993, p. 39

30 In July 1907, Li Wan promulgated Law No. 1 by the pro-Japanese anti-national cabinet, and on April 29, 1908, he made some amendments. However, on April 4, 1952 in the Korean War after the Japanese imperialism surrendered in 1945, it was repealed under the law No. 237. The law totals 41 article contains the "Newspaper Act" that emulates the Japanese Empire, but contains more stringent content than it does. Its characteristic is that in the process of establishing a news newspaper, it must obtain the permission of the internal minister and pay the deposit.

31 Zheng Jinxi, "The Anti-Japanese Cultural Movement of the Japanese Imperial Emperor's Forced Speech", The Second Humanities Research, 1982, p. 93

${ }^{32}$ Kim, Minnam, Kim, Yoowon, Park, Jidong, Yoo, yilsang, Lim, Donguk, Jung, Daesoo, "Rewritten History of Korean
} 
In addition, the situation in the Korean peninsula has developed in various directions by the nationalist movement against Japanese imperialist rule. Active activities such as anti-military struggles, the national debt compensation campaign, and the patriotic Enlightenment Movement, and the national campaign against Japan's development of wasteland requirements were included. The "Korean Daily News" supports this anti-Japanese national movement, arouses public opinion, and triggers diplomatic issues between Britain and Japan.

The "Korean Daily News" has greatly encouraged the Korean national camp. On the contrary, Japan and the United Kingdom are in awkward situations. Thomas Bethell has been sued twice by the Japanese side. At that time, he will always go to trial.

\subsection{Ethnographic Struggle - Based on "Daehan Daily News"}

The "Korean Daily News" founded by Thomas Bethell is one of the representatives newspaper in Korea, but it was the so-called "ethnographic" newspapers during this period. Since the issuer is British, he is fully utilized as a foreigner and enjoys extraterritorial protection. He can avoid repression from Japanese. Therefore, he includes General Manager Yang Gi-tak (1871-1938), Park Eun-sik (1859-1925), Sin Chaeho (1880-1936) and others as a strong anti-Japanese commentators.

On July 19, 1909, demonstrators who were dissatisfied with the pro-Japanese Korean attacked the pro-Japanese newspapers company and destroyed buildings and printing facilities. This newspaper company has persisted in many controversies with the "Daehan Daily News" because it has always adhered to stand against pro-Japanese Korean.

Peishuo sued the "north china daily news" for infringement of the reputation. In newspapers issued by Japan, China, the United Kingdom, and other countries, they regularly report on the lawsuits relating to the Peishuo and Yang Gi-tak. With regard to the "Daehan Daily News," Peishuo and Yang Gi-tak were tried as follows.

The first trial of Peishuo: In October 1907, the Japanese indicted Henry Cockurrn, the British Consul-General in South Korea, to sue Peishuo. The final decision in the case stated that he had been detained for six months. The second trial of Peishuo: In June 1908, Japan's Ma Yoshiyoshi, the secretary of the Chosun Department of Supervision, obtained authorization from the unified director and indicted Peishuo. In Shanghai, China's Supreme Court Justice of the High Court in China, H. B. Bourne (K. B. M. Bourne), came to the trial and sentenced him to guilty and was detained for three weeks. Yang Gi-tak's trial: In July 1908, Japan's excuse to arrest Yang Gi-tak for his attempt to punish the government for the purpose of corruption of the national debt repayment campaign. The incident led to diplomatic disputes between Britain and Japan. Yang Gi-tak eventually acquitted.

Peishuo initiates litigation against reputation of "north china daily news" and "N-Cherald" issued to British people in Shanghai, China. The case was tried in the High Court of the United Kingdom in Shanghai, China, in December 1908. In the end, Peishuo had won the case. "Yang Gi-tak's trial of security law violations": In January 1911 after the merger of South Korea and Japan in 1910, Yang Gi-tak and Lim Chi-jung (1880 1932) who were engaged in the "Daehan Daily News" were suspected of violating the "Security Law." He was arrested and imprisoned. Yang Gi-tak and Lim Chi-jung were sentenced for two years' imprisonment, and Ok Kwan-bin sentenced for one year and six months' imprisonment.

The trial of Yang Gi-tak and other "Shinmin (New citizens) Group" events (also known as 105 incidents): In January 1911, Japan arrested Yang Gi-tak, members of "Shinmin(New citizens) Group", and hundreds of nationalists. Yang Gi-tak and Lim Chi-jung was sentenced for ten-years, while Ok Kwan-bin was sentenced to six-years imprisonment. Later, in the public review of the Daegu Review Court, Yang Gi-tak and Lim Chi-jung were sentenced to six-years imprisonment, and Ok Kwan-bin was sentenced to five years in prison.

To summarize, the "Daehan Daily News" was founded by a British man, Peishuo. He enjoys extraterritoriality rights as an ordinary British private person in Korea. Therefore, Japan uses the British and Japanese countries as its allies as an excuse to find ways to expel Peishuo and restrict the newspaper

In fact, after the 1905 "Taiwan Treaty," the government of the Korean Empire was placed under the supervision of the Japanese imperialists in 1910, but it also had its own independent internal affairs, although very subtle. In addition, many factors such as the extraterritorial jurisdiction of the United Kingdom and Japan's policies have contributed to the more complex and difficult diplomatic representation of the "Daehan Daily News."

During this time period, including Peishou, Yang Gi-tak, and the British Consul-general in the South Korea, and

Speech", Book Publishing A-chim, August 1993 
other people have increased their difficulty in solving problems. After the fall of the Chosun Dynasty in 1910, Japanese imperialism continued to suppress the "Daehan Daily News." Japanese imperialism's diplomatic negotiations on giving pressure to the "Daehan Daily News" and attempt to expel Peisuo lasted from 1904 until 1910.

\section{Conclusion}

Before the modernization, there was a period under Lee's Chosun Dynastry where newspaper had the function of media for a while, but the traditional feudal monarchy cannot continue. In 1876, before the opening of the Japanese colony in 1910, the modernization of the Korean Peninsula began. The process of Korea's march toward modernization is very similar to that of China. The western forces did not directly reach the Korean Peninsula, but the interaction with western culture was later than that of China and Japan.

However, once it is modernized, news media has become a tool for civil rights awareness and national unity, world cognition and national subjectivity. By the end of the Russo-Japanese War in 1905, the pro-Japanese Korean in the Chosun Empire carried out the news media policy, and till 1910 "Korea-Japan Merger" the people were divided into "ethnography" and "pro-Japanese."

\section{Copyrights}

Copyright for this article is retained by the author(s), with first publication rights granted to the journal.

This is an open-access article distributed under the terms and conditions of the Creative Commons Attribution license (http://creativecommons.org/licenses/by/4.0/). 